\title{
CARL SCHMITT
}

Tekst został przetłumaczony na podstawie: C. Schmitt, Die Diktatur. Von den Anfängen des modernen Souveränitätsgedankens bis zum proletarischen Klassenkampf, Berlin 1994, s. 127149. Alle Rechte vorbehalten $(1994$ Duncker \& Humblot GmbH, Berlin. Serdecznie dziękujemy wydawcy za zgodę na publikację tłumaczenia.

\section{O pojęciu dyktatury suwerennej}

M ably i Rousseau nie do końca zdawali sobie sprawę, że wskazują na nadchodzącą dyktaturę rewolucyjną, jak to się okazało po doświadczeniach rewolucji. Rousseau poruszył kwestię dyktatury w czwartej księdze Umowy społecznej, traktując ją jednak jako problem rządów, a nie suwerenności. Zakładano wówczas, że dyktatura może wystąpić wyłącznie wtedy, gdy konstytucja zakłada istnienie „chef suprême”, który mianuje dyktatora i którego działania mieszczą się w ramach konstytucji nie ze względu na swoją treść, lecz z uwagi na podstawę prawną. Wszechmoc dyktatora opiera się zatem na upoważnieniu pochodzącym od istniejącego zgodnie z konstytucją, ukonstytuowanego organu - oto pojęcie dyktatury komisarycznej. Niezbyt dokładnie można natomiast określić przeciwieństwo dyktatury reformującej (Reformationsdiktatur), którą miał przed oczyma Mably. Przemiany politycznej i administracyjnej organizacji wspólnoty, określane mianem reform, zakładają oparcie się na ukonstytuowanym organie - papieżu czy absolutnym księciu - tak że źródło nowo powstającego porządku jest tożsame ze źródłem poprzedniego. W koncepcjach średniowiecznych nie istnieją problemy odróżnienia dyktatury komisarycznej od suwerennej, a tej z kolei od suwerenności jako takiej. Bóg, ostateczne źródło całej ziemskiej władzy, działa wyłącznie za pomocą Kościoła, stanowiącego trwale ustanowiony organizm. Nawet gdy koncepcję najwyższej osobowej jedności i jej osobowej reprezentacji, czyli papieża, zastąpiła zsekularyzowana idea suwerena, ograniczonego wprawdzie terytorialnie w swej władzy, ale mimo to „podobnego Bogu”, źródło całej ziemskiej władzy ciągle jeszcze pozostało

najwyższy zwierzchnik (fr.). Ten i pozostałe przypisy oznaczone gwiazdkami oraz informacje ujęte w nawias kwadratowy pochodzą od tłumacza. 
związane z wyobrażeniem ustanowionego organu. Także w koncepcjach monarchomachicznych ${ }^{*}$ pod pojęciem ludu (Volk) rozumie się ciągłą reprezentację [...]. Rozpad wszelkiej formy społecznej w religijnej reformacji i pismach protestanckich monarchomachów można rozpoznać po tym, że pozostawiono możliwość, by również ktoś niesprawujący żadnej ustanowionej funkcji, a będący jedynie „a Deo excitatus”, mógł usunąć istniejące zwierzchnictwo. W uzasadnieniu, jakie dał swej suwerenności Cromwell, najłatwiej rozpoznać, że pobożny protestantyzm w niewielkim stopniu rozpuścił istniejącą strukturę społeczną w szerokiej, ale nigdy nie ustanawiającej się samodzielnie wszechmocy narodu. Rewolucja purytańska była najbardziej jaskrawym przykładem złamania ciągłości istniejącego porządku państwowego. Przebrzmiała ona bez wywarcia długotrwałego wpływu na teorię państwa ówczesnych czasów ${ }^{1}$, choć w jej ramach pojawiły się wszystkie idee i postulaty radykalnej dziewiętnastowiecznej demokracji. W podaniach i projektach konstytucyjnych armii Cromwella wzmiankowano, że lud (the people) jest źródłem wszystkich politycznych uprawnień. Miejsce problemu monarchomachicznego, tj. stosunku reprezentacji ludowej do króla i rządu, zajął właściwy problem współczesnego państwa, czyli stosunek ludu do jego reprezentacji. Od 1647 roku, gdy zdawało się, że prezbiteriański Długi Parlament doszedł do porozumienia z królem, w dążącej do niezależności armii Cromwella wraz z ideami republikańskimi rozprzestrzeniała się również idea bezwarunkowej zależności parlamentu od ludu, z którym jednak armia (tzn. jej przedstawiciele) bez problemu się identyfikowała. W projektach konstytucyjnych pochodzących z ówczesnych czasów istotne jest stwierdzenie, że reprezentacja ludu zależy tylko od tego, kto ją wybrał. Władza przedstawicieli jest w przeciwieństwie do każdej innej (w domyśle - [władzy] przeciwnika politycznego, tzn. króla) nieograniczona, ale z nieuniknioną konsekwencją równie nieograniczonej zależności od ludu, który zastępują.

Umowa ludu (The Agreement of the People) z 28 października 1647 roku, która stała się sławna jako pierwszy ${ }_{2}$ projekt demokratycznej konstytucji w nowoczesnym tego słowa znaczeniu , została przygotowana przez lewelle-

\footnotetext{
Pojęcie użyte po raz pierwszy przez Williama Barclaya w wydanym w 1600 roku dziele De regno et regali potestate, adversus Buchananum, Brutum, Boucherium, \& reliquos monarchomachos, libri sex, Paris 1600 . natchniony przez Boga (łac.)

R. Gneist, Englische Verfassungsgeschichte, Berlin 1882, s. 578, zauważył, że również w zarządzaniu krajem nie pozostawiła żadnych śladów.

Przedruk: S. Gardiner, History of the Great Civil War, t. III, London 1898, s. 392; dalsze Constitutional documents, s. 333; G. Jellinek, Die Erklärung der Menschen- und Bürgerrechte, MünchenLeipzig 1919, s. 78. Na ten temat: W. Rotschild, Der Gedanke der geschribenen Verfassung in der englischen Revolution, Tübingen 1903, s. 92, oraz E. Zweig, Die Lehre vom pouvoir constituant, Tübingen 1909, s. 38 .
} 
rów, uznających Cromwella za zdrajcę, gdyż po upadku monarchii zachował dla siebie suwerenną władzę: Umowa z 1647 roku została przedłożona radzie wojskowej armii Cromwella jako projekt konstytucyjny, ów projekt rada zmieniła (20 stycznia 1648 roku) i przekazała do Izby Gmin wcale nie jako wyraz suwerennego ludu, lecz jako prywatną inicjatywę. Miesiąc później Cromwell powstrzymał działania lewellerów, które uznawał za marzycielstwo, nakazując uwięzić ich radykalnego przywódcę Johna Lilburne'a. W licznych ulotkach natychmiast wyrażono oburzenie $\mathrm{z}$ tego powodu, zarzucając politykowi, że jak wcześniej Anglia była rządzona przez króla, lordów i gminy, tak teraz - przez generała, trybunał wojskowy i gminy; że nie ma powszechnego prawa wyborczego itd. Te ważne dla historii idei politycznych pisma ${ }^{3}$ ukazują w interesującym nas kontekście, że kwestia suwerenności została już wówczas rozstrzygnięta - Cromwell był suwerenem. Pozostaje pytanie, czy jego władzę należy określać mianem dyktatury suwerennej.

Objęte przez siebie stanowisko - naczelnego dowódcy wszystkich sił zbrojnych w Anglii, Szkocji i Irlandii, mianowanego przez Długi Parlament Cromwell scharakteryzował w mowie z 12 września 1654 roku jako przekazanie nieograniczonego autorytetu. Był to przypadek dyktatury komisarycznej - porównywalnej z dyktaturą księcia Oranii - której sprawowanie powierzył mu Długi Parlament, suweren Commonwealthu oraz wolnego państwa Anglii. Dyktatura komisaryczna nie może rozwiązać parlamentu, od którego pochodzi - z tego powodu niełatwo było doprowadzić do dyktatury suwerennej. Jednak Cromwell rozwiązał Długi Parlament 20 kwietnia 1653 roku ${ }^{5}$. Wprowadzone w ten sposób interregnum Gneist określił jako „czystą dyktaturę wojskową" ${ }^{\prime 6}$ W rzeczywistości była to już suwerenność Cromwella. Parla-

G. P. Gooch, The History of English Democratical Ideas in the Seventeenth Century, Cambridge 1898 .

4 O. Cromwell, Letters and speeches, red. T. Carlyle, t. III, London 1904, s. 304 (nowe wydanie listów i mów Cromwella wydanych po raz pierwszy przez Carlyle'a w 1845 roku przez S. C. Lomasa; przekład niemiecki: O. Cromwell, Rede und Briefe, przeł. M. Stählin, Basel 1911, s. 374).

Na temat przebiegu historycznego por. esej: W. Michael, Oliver Cromwell und die Auflösung des langen Parlaments, „Historische Zeitschrift” $1889, \mathrm{nr} 63$, s. 56 , tam również dalsza literatura, a także: tenże, Cromwell, t. I, Berlin 1907, s. 274.

R. Gneist, Englische..., s. 580. Określenie to jest ogólne, ale bardzo niejasne. Por. S. Gardiner, History of the Commonwealth and Protectorate 1649-1660, t. II, New York-Bombay 1901, s. 282; A. Esmain, Éléments de droit constitutionnel français et comparé, „Revue du Droit Public et de la Science Politque en France et a l'Etranger" 1899, nr 12, s. 194; W. Michael, Cromwell, t. II, Berlin 1907, s. 5; E. Zweig, Die Lehre..., s. 47 (Militäroligarchie); J. Hatschek, Englische Verfassungsgeschichte bis zum Regierungsantritt der Königin Viktoria, München 1913, s. 339; G. Jellinek, Allgemeine Staatslehre, Berlin 1900, s. 675, przypis 1 [przekład polski: G. Jellinek, Ogólna 
ment (mały, nazwany szkieletowym), który zebrał się 4 lipca 1653 roku, składał się z przedstawicieli rady oficerskiej, ale został zwołany w imieniu Cromwella jako wodza naczelnego. 12 grudnia 1653 roku ów parlament zwrócił Cromwellowi swój mandat, gdy mu doniesiono, iż nie spełnił oczekiwań wodza. Wówczas, 16 grudnia 1653 roku, Cromwell proklamował Instrument rządzenia (Instrument of government), następnie sam został lordem protektorem czy też regentem państwa, a kompetencje legislatywy i egzekutywy w wyniku doświadczeń z Długim Parlamentem uregulowano w myśl dobrze przeprowadzonego rozdziału władz i daleko idącej niezależności władzy wykonawczej. Na podstawie Instrumentu 22 stycznia 1655 roku Cromwell ponownie rozwiązał zwołany parlament. Trzeci parlament, który zebrał się 17 września 1656 roku, uchwalił nową konstytucję, zgodnie z którą Cromwell stał się protektorem dożywotnio i miał prawo wskazać swojego następcę. 25 marca 1657 roku parlament zwrócił się do lorda protektora z prośbą, by przyjął imię, styl, tytuł i urząd króla Anglii, którą ten jednak odrzucił. Trzeci parlament także został rozwiązany przez Cromwella (4 lutego 1658 roku), który aż do swojej śmierci, tj. 3 września 1658 roku, rządził bez parlamentu, a jego syn Richard, na podstawie uznanej za określenie sukcesji wypowiedzi, stał się następnym lordem protektorem.

Biorąc pod uwagę ten stan rzeczy oraz stan prawny, Cromwell był suwerenem od rozwiązania Długiego Parlamentu. Jego wzgląd na oficerów własnej armii miał naturę czysto polityczną, polityk nie uznawał się za ich zleceniobiorcę. Powzięta z politycznej mądrości próba rządzenia przy pomocy parlamentu i konstytucji zmierzała ku temu, by własną suwerenność unormować konstytucyjnie, w ten sposób prawnie określając granice jej sprawowania. Pod tym względem Instrument rządzenia z 1653 roku można uznać za pierwszy przykład monarchii konstytucyjnej z oktrojowaną konstytucją. Decyzja odnośnie do "necessity of the State”, czyli tego, co teoria siedemnastego wieku określała mianem jura dominationis , nie pozostawiała wątpliwości, że Cromwell rozumiał suwerenność jako istniejącą ponad uregulowanymi kompetencjami, zasadniczo nieograniczoną pełnię władzy. Nie musimy tu rozsądzać, czy dalsze zabiegi były jedynie próbą powrotu do dawnego stanu metody rządzenia królowej Elżbiety, jak to przedstawił Gardiner, czy też naprawdę stanowią początki prawa konstytucyjnego w duchu dziewiętnastego wieku. Złamaniem związku prawnego, rewolucją było wyłącznie rozwiązanie Długiego Parlamentu w 1653 roku. Dalsze działania

nauka o państwie, ks. 1, przeł. A. Peretiatkowicz, Warszawa 1921; tenże, Ogólna nauka o państwie, ks. 2 i 3, przeł. M. Balsigierowa, M. Przedborski, Warszawa 1924].

stan wyższej konieczności (ang.)

prawo panowania (łac.) 
Cromwella były próbami opisania przez własną wolę ustanowionej w ten sposób suwerenności. O dyktaturze wojskowej można mówić tylko w czasie, kiedy po rozwiązaniu zebranego parlamentu na podstawie Instrumentu (22 stycznia 1655 roku) Cromwell rządził przez pewien czas poprzez jedenastu generałów, których można uznać za dyktatorów komisarycznych. Zostali oni oddelegowani, by ściągnąć specjalne podatki wojenne nałożone na rojalistów. Żeby utrzymywać porządek publiczny, rozbrajać przeciwników politycznych i aresztować wszystkich podejrzanych itd., dysponowali siłą militarną. W rzeczywistości działali jako komisarze wszystkich najwyższych uprawnień państwowych w przekazanych im obszarach. W mowie z 7 września 1656 roku Cromwell szczycił się własną służbą na rzecz przywrócenia spokoju publicznego. Rzeczywiście, owi komisarze są niezmiernie podobni do komisarzy Konwentu Narodowego, lecz ich dyktatura zawierała się w ramach suwerenności Cromwella, od której pochodziła. Miała ona charakter dyktatury wojskowej w znaczeniu dyktatury komisarycznej sprawowanej przez dowódców wojskowych, jednak Cromwell już w 1656 roku ją zlikwidował, ponieważ - jak stwierdził Gardiner - sprzeciwiał się każdemu rodzajowi dyktatury wojskowej ${ }^{7}$. Pozostaje zatem pytanie, czy wykonywana przez samego Cromwella suwerenność może być określona mianem dyktatury suwerennej.

Jeśli samo zniesienie podziału władz nazwać dyktaturą, to wówczas na to pytanie należy odpowiedzieć twierdząco. Jednak w każdym państwie absolutnym ma miejsce tego typu sytuacja, więc pojęcie dyktatury straciłoby całą jasność, gdyby stosować je do wszystkich tego typu przypadków. Politycznie mianem dyktatury można określić każde bezpośrednie sprawowanie władzy państwowej, tj. niezapośredniczone poprzez niezależne instancje pośrednie, w ten sposób rozumiejąc centralizm w opozycji do decentralizacji. W rozdziale pierwszym omówiłem już ogólny związek tej absolutystycznej idei z pojęciem dyktatury . Ponieważ jednak w organizacji wojskowej w sposób najbardziej wyraźny dominuje rozkaz wojskowy, wykonywany bez sprzeciwu i z „telegraficzną prędkością" (Berner), każdy system zbudowany na ścisłej dyscyplinie można nazwać dyktaturą. Przy specyficznej, prawnej naturze rozkazu wojskowego użycie pojęcia „dyktatura” było tym bliższe, że również dyktatura komisaryczna podlegała commissio w znaczeniu jednego z takich rozkazów. Za tym z kolei idzie wyjaśnienie powiązania pojęcia dyk-

S. Gardiner, Oliver Cromwell, London 1901, s. 167 (w niemieckim przekładzie: tenże, Oliver Cromwell, przeł. E. Kirchner, München 1903, s. 178).

Por. C. Schmitt, Die Diktatur. Von den Anfängen des modernen Souveränitätsgedankens bis zum proletarischen Klassenkampf, Berlin 1994, zwłaszcza rozdział I pt. Die kommissarische Diktatur die Staatslehre, s. 1-41. 
tatury z polityczną ideą cezaryzmu, ustanawianego poprzez zamach stanu, a przez to wprowadzającego w pojęcie dyktatury ideę przeciwieństwa legalnej monarchii. W ramach tego niejasnego i niezależnego od analizy prawnej wyobrażenia Cromwell i Napoleon są typowymi dyktatorami, dlatego że byli generałami. Jednak, by zrozumieć dyktaturę na poziomie abstrakcyjnym, należy się zatrzymać przy charakterze działań dyktatora. Zarówno w przypadku dyktatury suwerennej, jak i komisarycznej wyobrażenie stanu, do którego doprowadziły działania dyktatora, przynależy do pojęcia dyktatury. Prawna natura dyktatury polega na tym, że ze względu na cel, który należy osiągnąć, w konkretnej sytuacji pomija się zapory i hamulce prawne, stanowiące przeszkodę dla osiągnięcia celu. Wynika z tego, że wspomniane powyżej powstanie pruskiego absolutyzmu wojskowego nie było dyktaturą, także państwa policyjnego nie można określać tą nazwą, ponieważ ogólne polepszenie dobrobytu nie jest przedmiotem działania dyktatury. Jednakże państwo policyjne jako zasadę swej organizacji, w ogólnym zadaniu zarządzania, posiada element o zasadniczo komisarycznym charakterze i w tym względzie jest bliskie dyktaturze ${ }^{8}$. Jednak brakuje mu tego, co nadaje jego działaniu precyzyjną treść, to znaczy wyobrażenia konkretnego przeciwnika, którego usunięcie musi być celem działania. Określenie, o które tutaj chodzi, nie jest opartym na faktach zbiorem ustanowionym poprzez pojęcia prawne, lecz autentyczną specyfikacją. To, że w policyjnym państwie dobrobytu mamy wiele przypadków mniej lub bardziej warunkowych komisariatów działania, nie czyni z niego dyktatury suwerennej, ponieważ suwerenność nie jest prawnie zależna od realizacji konkretnego zadania i osiągnięcia określonego celu. Sukces osiągnięty dzięki działaniom dyktatora otrzymuje wyraźne kryterium przeciwnik, którego należało usunąć, natychmiast zniknął. Z punktu widze-

K. Wolzendorff, Der Polizeigedanke des modernen Staates, Breslau 1918, widzi w nastawieniu całego życia państwowego na salus publica [dobro publiczne] element, który był wspólny współczesnej myśli państwowej oraz policji. Wyłączna miarodajność salus publica niesie ze sobą „tendencję do wzrastającej intensywności i rozległości” (s. 11), stąd obszary regulowane przez policję „nieustannie wzrastały”, podczas gdy z drugiej strony państwo policyjne przez „obiektywną zmianę porządku państwowego" już zawarło [w sobie] przewodzący moment wspólnej woli państwowej, , abstrakcyjne i absolutne dążenie do zachowania autorytetu dla siebie” (s. 31). W ten sposób rzeczywiście zetknęły się „punkty krystalizacyjne" nowożytnego państwa, choć ukazują się one w innym kontekście, kiedy uwzględnić, że tendencja do ekspansji salus publica nie jest osobliwym prawem rozwoju, lecz wyrazem prostego stosunku między konkretnym celem a stosownym środkiem, który to stosunek zgodnie ze swoją logiczną naturą nie jest zdolny do żadnego wiążącego omówienia i w praktycznym zastosowaniu okazuje wszędzie dążenie do ekspansji, które powyżej zostało zilustrowane przykładem pruskiego komisarza wojskowego. O znaczeniu abstrakcyjnego dążenia do zachowania autorytetu jako takiego zob. C. Schmitt, Die Diktatur..., s. 22-24. Świetne przykłady prawniczej logiki celu u Ch. Wolffa, Jus naturae methodo scientifica pertractatum, VIII, $\S \S 110 \mathrm{i}$. 
nia psychologii wyobrażenie stanu nadchodzącego nigdy nie jest tak jasne, jak wyobrażenie stanu dostępnego bezpośrednio. Dokładne określenie przeciwnika jest wskutek tego możliwe poprzez negację stanu obecnego. Prawdziwą naturę postępowania tworzy zależność od tego, co czyni przeciwnik, która doprowadziła Locke'a do uzasadnienia szczególnej cechy federative power. Jak działanie w obronie koniecznej stanowi wedle swej definicji odparcie bezprawnego ataku i poprzez obecność owego ataku zostaje dookreślone, tak w przypadku pojęcia dyktatury należy trzymać się bezpośredniej aktualności stanu, który należy zlikwidować, w takim mianowicie sensie, że likwidacja wydaje się zadaniem prawnym, które prawnie uzasadnia pełnomocnictwo określone jedynie przez stan rzeczy i cel owej likwidacji. Jak pojęcie obrony koniecznej było niezależne od cech poszczególnych sytuacji, od techniki rzeczowej, która przynależy do ataku, a stąd również do niezbędnej obrony - rozwój broni palnej całkowicie odmienił konkretną treść działania w obronie koniecznej - tak pojęcie dyktatury ma zróżnicowaną treść zależną od stanu faktycznego, co jednak nie uzasadnia rozróżnienia na gruncie prawa między dyktaturą komisaryczną a suwerenną.

Podobnie jak działanie w obronie koniecznej, dyktatura jest zawsze nie tylko akcją, lecz także kontrakcją. Zakłada tym samym, że przeciwnik nie stosuje się do norm prawnych, które dyktator uznał za miarodajną podstawę prawną - za podstawę prawną, ale naturalnie nie za rzeczowy środek swoich działań. Przeciwstawienie normy prawnej (Rechtsnorm) i normy jej realizacji (Rechtsverwirklichungsnorm), które przebiega przez całe prawo, stało się przeciwstawieniem normy prawnej i rzeczowej reguły działania. Dyktatura komisaryczna uchyla konstytucję in concreto, by ją chronić w jej konkretnym istnieniu. Od dawien dawna powtarzano argument (najczęściej i najbardziej energicznie przez Lincolna): kiedy istnienie konstytucji jest zagrożone, należy je zabezpieczyć przez przejściowe zawieszenie konstytucji. Dyktatura chroni określoną konstytucję przez atakiem, który grozi jej zniesieniem. W sposób najbardziej wyraźny zarysowuje się tu metodologiczna samodzielność problemu realizacji prawa jako jednego z problemów prawnych. Działanie dyktatora powinno doprowadzić do stanu, w którym prawo może być realizowane, gdyż każda norma prawna zakłada stan normalny jako homogeniczne medium, w którym zachowuje ważność. Wskutek tego dyktatura jest problemem konkretnej rzeczywistości, nie przestając być kwestią prawną. Konstytucja może zostać zawieszona, nie przestając obowiązywać, ponieważ zawieszenie oznacza jedynie konkretny wyjątek. Należy również wyjaśnić, że konstytucja może być zawieszona tylko w wybranych obszarach.

władza federacyjna (ang.) 
Zdanie non potest detrahi a jure quantitas ${ }^{*}$ musiałoby jednakże zachować ważność również w tym wypadku, ponieważ w państwie, ustanowionym przez konstytucję jako pojęcie prawne, nie istnieje terytorialnie opisana przestrzeń, w której konstytucja nie obowiązuje, czy odcinek czasu, w którym nie ma ona ważności, czy określony krąg osób, które nie przestając być obywatelami, powinny być traktowane jak pozbawieni praw „wrogowie” czy „rebelianci". Takie wyjątki należą do istoty dyktatury i w ogóle są możliwe, ponieważ w ich przypadku chodzi o komisariat, określony zgodnie ze stanem rzeczy.

Dyktatura suwerenna w całym istniejącym porządku widzi stan, który poprzez swoje działania pragnie usunąć. Nie tyle zawiesza istniejącą konstytucję na mocy prawa mającego $\mathrm{w}$ niej swoje uzasadnienie, a zatem $\mathrm{z}$ nią zgodnego, lecz pragnie ustanowić stan umożliwiający istnienie konstytucji, którą uznaje za prawdziwą. Nie powołuje się na istniejącą konstytucję, lecz na przyszłą. Należałoby sądzić, że takie przedsięwzięcie unikałoby wszystkich rozważań natury prawnej. Ponieważ państwo może być rozumiane w sposób prawny jedynie poprzez swą konstytucję, totalna negacja istniejącej konstytucji musiałaby w rzeczywistości rezygnować z każdego uzasadnienia prawnego, ponieważ zgodnie z przesłankami przyszła konstytucja jeszcze nie istnieje. Wedle tego chodziłoby o samą kwestię władzy. Nie chodzi tu jednak o przypadek, kiedy ustanawia się władzę, która nie jest ukonstytuowana zgodnie $\mathrm{z}$ konstytucją, a mimo to znajduje się $\mathrm{z}$ nią $\mathrm{w}$ takim związku, że okazuje się uzasadniona także wówczas, gdy sama nie podlega konstytucji, i wskutek tego nie może zostać zanegowana przez to, że neguje istniejącą konstytucję. Oto znaczenie pouvoir constituant .

Pozycja księcia absolutnego nie zależy od wypełnienia określonego zadania, a jego uprawnienia nie stanowią upoważnienia wydanego ze względu na cel, który musi osiągnąć. Każdej dyktaturze przynależy komisariat i nie wiadomo, czy istnieje komisariat możliwy do pogodzenia z suwerennością i w jakiej mierze sprzeciwia się ona pojęciu suwerenności tym, że jest zależna od misji. Osobliwość pouvoir constituant umożliwia taki rodzaj zależności, ponieważ - z powodu charakteru pouvoir jako nieukonstytuowanej i niemożliwej do ukonstytuowania - jest możliwe, że posiadacz władzy państwowej sam siebie czyni zależnym, mimo że władza, od której czyni się zależnym, staje się ukonstytuowanym suwerenem i mimo że z drugiej strony zanika każda dalsza ziemska instancja, jak w przypadku zależności suwerena od Boga. Cromwell powoływał się w swojej misji na Boga. Kiedy okazjonalnie wypowiadał się o zgodzie ludu na jego przywództwo, w decydującym mo-

\footnotetext{
nie można nic ująć prawdziwej wielkości (łac.)

władza ustrojodawcza (fr.)
} 
mencie - jak w przypadku rozwiązania Długiego Parlamentu - nigdy nie miał wątpliwości, że źródło swojej władzy widzi w Bogu, a jego suwerenność nie jest zależna od ludu w rozumieniu współczesnych mu radykalnych demokratów. W wielkiej mowie z 12 września 1657 roku wygłoszonej przed zgromadzonym parlamentem wyjaśnił, że obawia się popełnić grzech, zbyt wcześnie oddając parlamentowi otrzymaną od Boga władzę, i że raczej woli umrzeć okryty hańbą, niż ujrzeć ustanowiony przez Boga protektorat wypaczony przez parlament. Parlament potwierdził jego pozycję jako protektora oraz suwerenność, mimo że od teraz formalnie jej podstawą prawną stałaby się zgoda tego organu. Cromwell mógł w każdej chwili rozwiązać parlament, co też uczynił, a rozwiązanie nie było bynajmniej apelem do ludu. Rozwiązując w 1658 roku trzecie z kolei zgromadzenie, Cromwell stwierdził, że to Bóg powinien być sędzią, w ogóle natomiast nie wspomniał o ludzie. Słusznie Esmein określił definicję konstytucji Cromwella - była ona jedynie dobrowolnym samoograniczeniem posiadacza władzy pochodzącej od Boga ${ }^{9}$. Protektor miał osobistą misję, likwidacja istniejącego porządku nie była racjonalnie uzasadniona, lecz stanowiła przypadek szczególny, który monarchomachiczna teoria państwa określała mianem przypadku a Deo excitatus $^{10}$. Nie da się zupełnie zrozumieć tego procesu za pomocą kategorii prawnych. Mówiono o dyktaturze, że jest cudem, co uzasadniano tym, że zawieszenie praw państwowych można porównać z zawieszeniem praw natury przez cud $^{11}$. W rzeczywistości dyktatura nie jest cudem, lecz przełamaniem związku prawnego, zależnym od nowo ustanowionego przywództwa. Zarówno dyktatura komisaryczna, jak i suwerenna istnieją w związku prawnym. Dyktatura suwerenna powołuje się na pouvoir constituant, której nie może usunąć stojąca jej na przeszkodzie konstytucja. Bóg jest odmiennym dawcą poleceń niż ów posiadacz pouvoir constituant, a zrządzenie boskie, opatrzność (która, jak trafnie zauważył Esmein, w przypadku Cromwella oznaczała to samo, co w filozofii historii Bossueta) to coś innego niż acte

A. Esmein, Cours d'histoire du droit français, Paris 1908, s. 209. Gardiner w biografii Cromwella swego autorstwa stwierdzil, że ani Cromwell, ani Milton nie nadaliby narodowi jako takiemu prawa; jeśli wola narodu nie zgadza się z boską, tym gorzej dla narodu.

Junius Brutus, Vindiciae contra Tyrannos, Edinburgh 1579, s. 68. Najczęściej czytanym monarchomachicznym tekstem było wówczas dzieło G. Buchanana, De jure regni apud scotos. W 1648 roku ukazał się także angielski przekład Vindiciae (W. Michael, Cromwell..., t. I, s. 184, por. E. Zweig, Die Lehre..., s. 31).

Donoso Cortés w swojej wielkiej mowie wygłoszonej 4 stycznia 1849 roku w hiszpańskiej izbie deputowanych (francuskiego przekładu dokonał Louis Veuillot, niemieckiego Hans Abel - w piśmie związku „Glaube und Treue”, z. 1, München 1920) [przekład polski: J. Donoso Cortés, O dyktaturze, przeł. N. Łuczyńska, W. Przybylski, „Res Publica Nowa” 2007, nr 1, s. 150-160]. 
impératif ${ }^{*}$ jak realizację pouvoir constituant definiował Boutmy ${ }^{12}$. Bezpośredni komisarz ludowy nie ma już jednak tak silnego punktu oparcia dla swojej zależności jak komisarz absolutnego księcia. Charakterystyczna dla dawnego komisarza konstrukcja zakładająca, że reprezentuje on kogoś innego i czyni to, co uczyniłby zastępowany, gdyby sam działał - vices gerit nadal jeszcze oddziaływała, choć w kontekście ludu, który jest zastępowany, otrzymała całkowicie nową treść ${ }^{13}$. Już Bodin zauważył, że istotną różnicę stanowi to, czy dla komisarza miarodajna jest wola księcia czy ludu, pojedynczego człowieka czy wielu tysięcy ludzi ${ }^{14}$.

\section{akt władczy (fr.)}

12 É. Boutmy, Etudes de droit constitutionnel, Paris 1909, s. 241. Gdy w literaturze monarchomachicznej poruszano kwestię potestas constituens w przeciwieństwie do potestas constituta, nigdy nie pomijano tego, że lud jest ukonstytuowany przez samego Boga; Althusius, Politica, Herborn 1625, XVIII 93, XIX 19 i n.

dosł. sprawować zamiast (łac.)

13 W dziewiętnastowiecznych konstytucjach istniała idea, że książę (szczególnie w przypadku zaprzysiężenia posłów i rozpoczęcia działania parlamentu krajowego) jest osobiście reprezentowany przed parlamentem przez komisarza; por. konstytucja heska, Art. 62, 81, 85, 88, 89, 96, 98, 101 (F. Stoerk, Handbuch der deutschen Verfassungen: die Verfassungsgesetze des Deutschen Reiches und seiner Bundesstaaten nach dem gegenwärtigen Gesetzesstande, Lepzig 1884, s. 195-201); Reuß j. L., § 88, 89, 91 (tamże, s. 315); Konstytucja saksońska, \$133, 135 (tamże, s. 343; O. Mayer, Das Staatsrecht des Königreichs Sachsen, Tübingen 1909, s. 146); SachsenAltenburg, § 221, 222, 232-234, 242 (F. Stoerk, Handbuch..., s. 383-386); Coburg und Gota, $\S 77$ (tamże, s. 401); Sachsen-Meininger, Art. 92, 94 (tamże, s. 431-432); Sachsen-WeimarEisenach, § 27, 29 (tamże, s. 440); Schaumburg-Lippe, Art. 23, 25, 26 (tamże, s. 451); Schwarzburg-Sondershausen, $\$ 66$ (nie ma tutaj wprawdzie mowy ani o komisarzu, ani o pełnomocniku, lecz o „oddelegowanym urzędniku”; tamże, s. 478); Waldeck, §56, 63 (tamże, s. 488); Anhalt (1859), § 24 (tamże, s. 64); Baden, § 68, 76, 77 (tamże, s. 84-86); Bayern VII, $\$ 22$ (tamże s. 103; na temat komisarza parlamentu krajowego wedle ustawy bawarskiego parlamentu krajowego z 25 lipca 1850 roku: Art. 10, 14; M. von Seydel, Bayerisches Staatsrecht, Tübingen 1913, s. 302); Braunschweig, § 131 (F. Stoerk, Handbuch..., s. 131); Lübeck, Art. 61 (Komisarze senatu, tamże, s. 230; w Hamburgu i Bremie natomiast nie istniał tego rodzaju komisarz); Lippe, $\$ 27$ (tamże, s. 206); Oldenburg, Art. 151, 156 (tamże, s. 259); Preußen, Art. 77, Reuß ä. L. § 64, 78, ust. 3. Nazwa „komisarz” została zachowana dla przedstawiciela rządu, który w imieniu ministra uczestniczył w dyskusjach parlamentarnych. Na pytanie, czy komisarz rządowy podlegał dyscyplinie parlamentarnej, można odpowiedzieć dopiero po wyjaśnieniu, czy był on w dawnym sensie osobowym reprezentantem księcia, czy też nie. Gdzie w republice minister może być reprezentowany przez komisarza (por. Art. $6 \S 2$ konstytucji francuskiej z 16 lipca 1785: sur les rapports des pouvoirs publiques, który co do treści wywodzi się z Art. 69 konstytucji z 1848 r.), tam komisarze rządowi są jedynie pomocnikami ministra i są ograniczeni tym, by reprezentować w parlamencie poglądy rządu; są jedynie „porte-parole”, a odpowiedzialny jest minister (L. Duguit, Traité de droit constitutionnel, t. II, Paris 1923, s. 316, 319, 498). O konstytucji Rzeszy z 1871 por. K. Perels, Die Legislaturperiode des preussischen Hauses der Abgeordneten und des deutschen Reichstages, „Archiv für öffentliches Recht” 1905, t. 19, s. 14 i n.

J. Bodin, Les six livres de la République, Paris 1580, s. 389 [J. Bodin, Sześć ksiag o Rzeczypospolitej, przekład zbiorowy, Warszawa 1958, s. 301-302]. 
Ideę pouvoir constituant rozpowszechnił Sieyès ${ }^{15}$, przede wszystkim dziełem o stanie trzecim. Zgodnie z nią wszystkie istniejące władze zostały uzależnione od ważności praw, reguł i form, do których zmiany nie mogą same doprowadzić, ponieważ podstawą ich istnienia jest konstytucja. Wedle tego władza ukonstytuowana zgodnie z konstytucją nie może stać ponad konstytucją, gdyż jako regulacja związku, podobnie jak podział władz, jest ona swoją własną podstawą. W ten sposób wszystkie ukonstytuowane władze odnoszą się do konstytucyjnie uzasadnionej, konstytuującej władzy. Jest ona zasadniczo nieograniczona i może absolutnie wszystko, ponieważ nie jest uzależniona od konstytucji, lecz sama nadaje konstytucję. Całkowicie nie do pomyślenia są tutaj jakieś przymus czy forma prawna, jakieś samoskrępowanie, obojętnie w jakim znaczeniu, a niezbywalne prawa człowieka są bezprzedmiotowe tam, gdzie rządzi volonté générale $\mathrm{w}$ rozumieniu Rousseau. Lud jako posiadacz konstytuującej władzy nie może być związany i w każdej chwili jest upoważniony do tego, by nadać sobie dowolną konstytucję. Konstytucja jest ustawą zasadniczą (loi fondamentale) nie dlatego, że jest nieodwołalna i niezależna od woli narodu, lecz ponieważ wszystkie organy działające $\mathrm{z}$ autorytetu państwa nie mogą niczego zmienić w tejże konstytucji, na którą powołują się ich uprawnienia. Dotyczy to również ustawodawstwa powszechnego.

Teoria państwa, wedle której państwo jako całość działa dzięki organom - poprzez działanie organów powstaje wola państwowa, ale nie jest reprezentowana, tak że poza ich działaniem ona nie istnieje - musi ujmować teorię pouvoir constituant jako próbę, by z ludu jako takiego uczynić organ państwa, przez co posiadanie władzy ustrojodawczej staje się kwestią organizacji organów konstytucyjnych. W konstrukcjach G. Jellinka państwo jest ogółem wszystkich funkcji organów, lecz nigdy „samo nie objawia się jako podmiot ogółu swoich funkcji, lecz jedynie jako obdarzony kompetencjami, a stąd nimi ograniczony organ”, nigdy jako „po prostu państwo”, lecz zawsze wyłącznie ,jako państwo pod postacią określonej kompetencji”. Kompetencja jest formą objawiania się państwa, które „posiada” prawo będące podstawą dla kompetencji organu. Substancja państwowa (jest bez znaczenia, czy się odrzuci to pojęcie jako scholastyczne, czy też nie) „ukazuje się” jedynie poprzez medium kompetencji, zawsze jako ograniczona władza. Jednostki, realizujące ową organiczność, nie powinny być mylone ani z państwem, ani z organem państwa, któremu jako takiemu zupełnie brakuje własnej podmiotowości; również najwyższy organ państwa jest jedynie organem, a

15 E. Sièyes, Czym jest stan trzeci?, [w:] Filozofia francuskiego Oświecenia, red. B. Baczko, Warszawa 1961, s. 402-406.

wola powszechna (fr.) 
zmiana konstytucji kompetencją ${ }^{16}$. Jeśli ktoś chciałby sprowadzić tę teorię do skrajności, musiałby stwierdzić, że państwo, które wedle niej istnieje jedynie w działalności organów, uznaje ona za wspornik całości, ale jako wspornik, który niczego nie może podeprzeć, gdyż sam jest podpierany przez organy, które podpiera. Nie posiada on żadnej więcej kompetencji, lecz jest kompetencją. Kiedy Jellinek mówi o środku, dzięki któremu ukazuje się wola państwowa, nie ma na myśli pośrednictwa w rozumieniu teorii władzy pośredniej, ponieważ wola powstaje bezpośrednio poprzez rzekomo pośredniczący organ. Absolutne pośrednictwo poprzez organy państwa staje się tożsame $\mathrm{z}$ absolutną bezpośredniością woli, ukazującej się dzięki organom państwowym. „Za organami nie stoi żadna inna osoba, lecz są one samym wyrażającym wolę państwem".

Te wiele dyskutowane, dobrze znane słowa zostały tutaj przytoczone, by wyraźniejszym uczynić ich przeciwieństwo w stosunku do teorii pouvoir constituant. Niezwykle wartościowemu historycznemu przedstawieniu tej teorii dokonanemu przez Egona Zweiga zaszkodziło to, że ukazał on rozwój jako przejście od materialnego do formalnego pojęcia konstytucji, a główny punkt teorii nazwał ,jeśli nie produktem, to świadectwem epoki oświecenia", która w swym racjonalizmie wierzyła w mechaniczne skonstruowanie państwa $^{17}$. W rzeczywistości racjonalizm osiągnął punkt krytyczny już w Umowie społecznej. Punkt kulminacyjny racjonalizmu stanowi próba Condorceta, by zracjonalizować prawo oporu przez uregulowania prawne ${ }^{18}$. Teoria Sieyèsa jest $\mathrm{w}$ przeciwieństwie do tego zrozumiała wyłącznie jako wyraz chęci znalezienia tego, co organizujące, a nie do zorganizowania (das unorganisierbar Organisierende). Przedstawienie relacji pouvoir constituant do

${ }^{16}$ G. Jellinek, Das System der subjektiven öffentlichen Rechte, Tübingen 1892, s. 228, 231, 225, 229. Gdy na s. 229 cytowana jest wypowiedź Blackstone'a, że król zawsze jest obecny w swoich trybunałach, nawet wówczas, gdy nie może osobiście wykonywać prawa, Jellinek szuka związku między swoją teorią a ideą króla obecnego wszędzie poprzez urzędy, sprzeciwiając się tym samym swojej teorii, ponieważ słowa Blackstone’a należy wyjaśniać przez dawne przedstawienie osobistych reprezentantów, qui vices gerit, a nie „obdarzony kompetencjami” organ, za którym nie stoi żadna wola, którą reprezentuje, lecz najpierw tę wolę wytwarza.

17. Zweig, Die Lehre..., s. 4.

18 Według Wolzendorffa, który docenił poglądy i koncepcje Condorceta oraz wskazał na jego wielkie historyczne znaczenie, prawo sprzeciwu przez Condorceta zostało „przekierowane" do organizacji prawnej (K. Wolzendorff, Staatsrecht und Naturrecht, Breslau 1916, s. 390). Nie można jednak przeoczyć, że przez to została zniesiona liberalna zasada rozdziału między zasadniczo nieograniczoną jednostką a z zasady ograniczonym państwem (por. C. Schmitt, Die Diktatur..., s. 116), a prawo oporu z prawa człowieka i prawa do wolności stało się kompetencją, tzn. państwowo przyznanym prawem obywatelskim. Jeśli owo prawo „organizować", wówczas ulega ono wynaturzeniu; skoro tylko zostało zracjonalizowane, to jest racjonowane. 
pouvoir constitué posiada doskonałą systematyczną i metodyczną analogię $\mathrm{w}$ przedstawieniu stosunku natura naturans i natura naturata ; to przedstawienie zostało przejęte $\mathrm{w}$ racjonalistycznym systemie Spinozy, co dowodzi, że nie ma on charakteru wyłącznie racjonalistycznego. Również teoria pouvoir constituant jest nie do zrozumienia wyłącznie jako mechanistyczny racjonalizm. Lud, naród, siła pierwotna wszystkich bytów państwowych konstytuują coraz to nowe organy. Z nieskończonej, niewyobrażalnej otchłani tej siły ukazują się coraz to nowe formy, które może ona zniszczyć w każdym momencie i w których jej władza nigdy definitywnie się nie ogranicza. Może ona pragnąć dowolnych rzeczy, treść jej woli ma zawsze taką samą wartość prawną jak treść regulacji konstytucyjnej. Może zatem dowolnie ingerować w ustawodawstwo, wymiar sprawiedliwości oraz same faktyczne akty. Staje się ona nieograniczonym i niemożliwym do ograniczenia posiadaczem jura dominationis, który jednak niejeden raz wymagał ograniczenia w razie pilnej potrzeby. [Ta siła] nigdy nie konstytuuje siebie samej, lecz zawsze coś innego. Jej związek z ukonstytuowanym organem nie jest zatem wzajemnym stosunkiem prawnym. Naród zawsze znajduje się w stanie natury, jak głosi znana sentencja Sieyèsa. W teorii stanu natury istotnym założeniem było to, że istnieją w nim wyłącznie jednostki. Często występująca zmiana - w stanie natury istnieje naród -w przeciwieństwie do tego nie oznaczała, jak niegdyś, że w stanie natury jest on przeciwko innym narodom. Nie chodzi tu o odnoszącą się do prawa międzynarodowego konstrukcję, lecz o stosunek narodu do jego własnych form, zgodnych z konstytucją, i wszystkich występujących w jego imieniu funkcjonariuszy. Naród znajduje się w stanie natury jednostronnie, ma jedynie prawa, a żadnych obowiązków, pouvoir constituant nie jest z niczym związane, pouvoir constitué odwrotnie - ma jedynie obowiązki, a żadnych praw. Warta zauważenia konsekwencja: jedna część zawsze pozostaje w stanie natury, a druga w stanie prawa (lub lepiej - obowiązku).

$\mathrm{Z}$ tym Sieyès wiąże dopuszczalność reprezentacji. Postrzegał on posłów zgromadzenia ustawodawczego z 1789 roku jako reprezentantów w przeciwieństwie do posiadaczy mandat impératif ; nie powinni być oni przedstawicielami i przekazywać już ustalonej woli, lecz ją najpierw „formować”. Podkreślił tym samym, że nowożytne państwo składa się z innej ludności niż antyczna republika i dziś, w epoce podziału pracy, jedynie mała część ludzi ma czas i zdolności, by zajmować się rzeczami politycznymi, a pozostali myślą „,bardziej o produkcji i konsumpcji”, tak że stali się po pro-

\footnotetext{
* władza ustanowiona (fr.)

* natura rodząca (łac.)

**** natura zrodzona (lac.)

mandat imperatywny (fr.)
} 
stu pracującymi maszynami (machines de travail) ${ }^{19}$. Stąd wyłania się osobliwy związek ze wszechmocą konstytuującej woli. Również gdy wola ludu merytorycznie w ogóle nie istnieje, lecz jest najpierw formowana poprzez reprezentację, utrzymana zostaje bezwarunkowa, w charakterystycznym sensie tego słowa, komisaryczna zależność reprezentantów od woli. Wola może być niejasna, a nawet musi mieć taki charakter, jeśli pouvoir constituant jest rzeczywiście niekonstytuowalna. Ta wyrażona przez Sieyèsa konsekwencja wskazuje na całkowicie przeciwną racjonalizmowi filozofię XIX wieku, w której Bóg jako coś „obiektywnie niewyjaśnionego” stanowi centrum świata, jak nieposiadające formy, ale zawsze tworzące nowe formy pouvoir constituant - centrum życia państwowego. Zależność funkcjonariuszy politycznych, którzy występują w imieniu ludu, nie przestaje jednak być konieczna. Jeszcze bardziej niż Rousseau, Sieyès podkreślał, że każde działanie organów państwowych ma jedynie naturę komisaryczną, a substancja państwowa, czyli naród, w każdej chwili może wystąpić bezpośrednio w pełni swojej władzy. Utrzymuje się więc korelacja większej władzy na zewnątrz z większą zależnością od wewnątrz, ale jedynie formalnie. Najważniejszym założeniem dla tego, że wola rządzi i dyktuje, byłoby to, że im wola jest precyzyjniejsza, tym silniejsza powinna być zależność. Ideałem bezwarunkowo rządzącej woli byłby rozkaz wojskowy, którego pewność natychmiastowości, z jaką powinien zostać wykonany, musi być odpowiednia. Stanowczość rozkazu nie jest oczywiście pewnością formy prawnej, lecz precyzją techniki rzeczowej. Stosunek komisaryczny jest również podporządkowany idei konkretnego działania, ingerującego w związek przyczynowy. Do bezwarunkowej komisarycznej zależności reprezentantów należał właściwie mandat impératif. Tej konsekwencji Sieyès jednak nie wyciągnął, uzasadniając, że wola ludu nie jest precyzyjna co do treści. Wola dotyczy zatem jedynie osoby reprezentanta i decyzji, czy reprezentacja powinna się utrzymać, czy nie. W rzeczywistości wola może być nieprecyzyjna, ponieważ skoro tylko w jakiś sposób się uformuje, przestaje ona być konstytuującą się, a jest ukonstytuowaną.

Reprezentanci działający w imieniu pouvoir constituant są zatem formalnie bezwarunkowo zależnymi komisarzami, których zadania nie da się merytorycznie określić. Prawdziwa treść zadania musi być uzana za najogólniejsze, zasadnicze kształtowanie konstytuującej woli, a zatem za projekt konstytucji. Jednak nie z powodu prawnej natury konstytucji również faktyczne posunięcia mogą być wzięte za wolę ludu. W przeciwieństwie do zwyczajnych przedstawicieli, przedstawiciele nadzwyczajni, czyli ci, którzy bez-

E. Sieyès, Mowa z 7 września 1789, Arch. Parl. VIII 532. 
pośrednio wykonują pouvoir constituant, mogą mieć każde dowolne pełnomocnictwo. Wykonywanie pouvoir constituant musi przy tym zawsze być odróżnione od jej substancji, w przeciwnym razie konstruowałaby się w swoich nadzwyczajnych reprezentantach. Jeśli reprezentanci mieliby zadanie opracowania konstytucji, mogliby, zależnie od wykładni treści zadania, ustanowić konstytucję samodzielnie lub poddać ją pod referendum ludowe. W każdym wypadku, gdyby to się wydarzyło, zadanie zostałoby wypełnione.

Może się jednak zdarzyć, że wykonanie pouvoir constituant ludu będzie niemożliwe i stan rzeczy domaga się najpierw usunięcia przeszkody, by zwrócony przeciwko pouvoir nacisk został zlikwidowany. Wola ludu może zostać zniewolona przez wymuszony środek i zewnętrzny nacisk lub przez ogólne zamieszanie i nieporządek stosunków. Należy tutaj wyróżnić dwa przypadki. „Żeby lud mógł dokonać aktu konstytuującego w sile swej suwerenności, musi - według Borgeauda ${ }^{20}$ - mieć wybór między poprzednim i nowym reżimem. Po rewolucji tradycja została przerwana, a stara konstytucja już nie istniała i przez to, że ludowi przedłożono nową, w rzeczywistości część suwerenności została zrealizowana przez przedkładających nową konstytucję. Potrzeba porządku jest zbyt duża, by osąd ludu pozostał wolny w takim stanie rzeczy”. To może ,justifier l'action d'un pouvoir révolutionnaire édictant une charte provisoire" ", jednak gdy nowy rząd się ukonstytuował, a porządek został zaprowadzony, to wówczas już nie powinno. Można było sprawić, by te same rozważania obowiązywały również już przed nieładem wprowadzonym przez rewolucję, gdy istniejący porządek postrzegano jako przeszkodę dla wolnej realizacji pouvoir constituant, tak że zawsze możliwe są nowe rewolucje i ponowny apel do pouvoir constituant. Zadanie oczyszczenia drogi poprzez rewolucyjne usunięcie istniejącego porządku powołałoby się potem również na pouvoir constituant i uczyniło od niej zależnym. W obydwu przypadkach dochodzi do powstania komisariatu, jak w wypadku dyktatury komisarycznej, a pojęcie pozostaje funkcjonalnie zależne od idei prawdziwej konstytucji, ponieważ również w sytuacji dyktatury rewolucyjnej konstytucja wprowadzana przez dyktaturę i zawsze istniejąca pouvoir constituant są zawieszone. Podczas gdy dyktatura komisaryczna jest upoważniona przez ukonstytuowany organ i ma swój tytuł w istniejącej konstytucji, suwerenna jest wywodzona jedynie quoad exercitium ${ }^{* *} \mathrm{z}$ niemającej formy pouvoir constituant. Jest prawdziwym komisariatem, a nie - jak powołanie na misję transcendentnego Boga - odrzuceniem każdej dalszej ziemskiej pochodnej. Apeluje ona zawsze do istniejącego ludu, który w każdej

\footnotetext{
* Ch. Borgeaud, Etablissement et révision des constitutions, Paris 1892, s. 409.

* uzasadnić działania władzy rewolucyjnej, by wprowadzić konstytucję tymczasową (fr.) ze sposobu wykonywania (łac.)
} 
chwili może wkroczyć do akcji i w ten sposób mieć bezpośrednie znaczenie prawne. „Minimum konstytucji” istnieje tak długo, dopóki pouvoir constituant jest uznawana ${ }^{21}$. Jednak ponieważ dla tego samego narodu najpierw należy ustanowić zewnętrzne warunki, by jego władza konstytuująca mogła się zaktualizować, jest samo w sobie problematyczną treścią konstytuującej woli w stanie rzeczy, poprzez który owa dyktatura jest uzasadniona, nie realizować własnych założeń. Władza dyktatorska jest suwerenna, lecz jedynie jako „przejście” i - z powodu jej zależności od zadania, które należy zrealizować w zupełnie innym sensie niż absolutny monarcha czy suwerenna arystokracja. Dyktator komisaryczny jest bezwarunkowym komisarzem pouvoir constitué, a dyktatura suwerenna-komisariatem pouvoir constituant ${ }^{22}$.

${ }^{21}$ Tylko z tego powodu, a nie z racji „faktycznej, podtrzymującej jedność państwa władzy”, jak chce G. Jellinek, Allgemeine Staatslehre..., s. 491.

Istnieją tutaj dwa przedstawienia, których dalsze doskonalenie prowadzi do dziewiętnastowiecznej filozofii państwa - lud oraz postęp historyczny. Despotyzm oświeceniowej filozofii dotyczący wychowania został uzależniony od wypełnienia pewnego zadania. Odwoływał się do wiary w zdolność doskonalenia rodzaju ludzkiego, prowadzącej do filozofii historii postępu, który dokonuje się ponad pojedynczym człowiekiem. W dwóch całkowicie różnych dziewiętnastowiecznych systemach - Comte'a i Hegla - teoria postępu w ramach filozofii historii została systematycznie ugruntowana. Turgot wcześniej wyraził Comte'owskie tzw. prawo trzech stadiów rozwoju ludzkości (stadium teologiczne, metafizyczno-abstrakcyjne oraz pozytywne) oraz społeczną zależność jednostki od otoczenia, a Szkic obrazu postępu ducha ludzkiego poprzez dzieje Condorceta przekroczył już w takim stopniu racjonalizm osiemnastego stulecia, że Bonald zasadnie mógł go określić mianem „apokalipsy oświecenia”. Postęp pozostaje jednakże zawsze dziełem świadomego ludzkiego działania, a treść zadania dyktatora polega na tym, by osiągnąć ten postęp, co stanowi przeciwieństwo immanentnego pojmowania postępu obecnego w dziewiętnastym stuleciu, jak trafnie zauważył Renouvier. Często przedstawiano elementy filozofii Kantowskiej odnoszące się do filozofii historii. Szczególnie istotne są tutaj wskazania Ericha Kaufmanna - Kant używał pojęcia organizmu jako opozycji do mechanizmu osiemnastego wieku. Jest to istotnie decydująca zmiana. Poza tym Kantowska filozofia prawa jest summą racjonalnego prawa naturalnego, które zostało rozwinięte z największą konsekwencją i niesamowitą jasnością, biorąc za punkt wyjścia współistnienie ludzi. Stąd nie istnieje dla Kanta ani prawo wyższej konieczności (które dla niego jest przymusem bez prawa) ani łaska. W przeciwieństwie do tego przejście do filozofii historii u Fichtego jest już niezwykle czytelne. Można wskazać tutaj na interpretację Emila Laska, do której można dodać, że głównym punktem jest wyobrażenie dyktatora, „tyrana”, który znajduje się „na szczycie wglądu w swoje czasy i swój lud”. Nie ma „jedynie obliczającej, warunkowej woli”, którą realizuje „świerszcz”, jak Napoleon, lecz jest „zachwycony”, posiadając wolę „absolutną". Jest on „tyranem powołanym przez Boga”, „formą wedle tyrana i uzurpatora”, który najpierw stworzył ludzi, a później uczynił ze zmuszonego swojego sędziego (wyjątkowo ważny opis wyobrażenia dyktatury suwerennej); ludzkość ,jako opierająca się natura” jest poddana „władzy prawa i wyższego względu bez łaski i pobłażliwości dla tego, czy to rozumie, czy nie", państwo nie może wprawdzie stać się panem natury o tyle, o ile nie może stać się „fabryką dzieci”, dlatego powinno stać się „fabryką kształcenia” (J. G. Fichte, Sämtliche Werke, t. VII, Berlin 18451846, s. 576 i n., 435 i n.). Bardziej dobitne jest pominięcie punktu, w którym legalny oświeceniowy despotyzm zyskuje charakter filozoficzno-historyczny. W Heglowskiej filozofii jest miejsce dla dyktatury tylko o tyle, o ile co do treści może być ona dziejowym zadaniem 
Konwent Narodowy, który zebrał się 20 września 1792 roku, miał za zadanie opracować konstytucję, będąc nadzwyczajnym organem pouvoir constituant. Po tym, jak ułożył on konstytucję (z 24 lipca 1793 roku), a lud ją przyjął w powszechnym głosowaniu, jego zadanie, a zatem i jego upoważnienie, zostało wypełnione. $Z$ powodu stanu wojny i wewnętrznych działań antyrewolucyjnych, które zagrażały istnieniu nowej konstytucji, 10 października 1793 roku Konwent uchwalił, że tymczasowy rząd Francji będzie „rewolucyjny” aż do nastania pokoju. Tym samym konstytucja z 1793 roku została zawieszona, nie weszła też już w życie. Chociaż w tym wypadku zawieszono konstytucję już przyjętą, jest to przypadek dyktatury suwerennej. Wykonawszy swoje zadanie, Konwent przestał być ukonstytuowanym organem. O zawieszeniu konstytucji nie było mowy ani w zleceniu projektu konstytucji, ani w samej konstytucji. Nie istniał zatem ukonstytuowany organ,

„historycznej osobowości” (Napoleon), lecz stojący na przeszkodzie stan, który dyktator ma zlikwidować, jako negacja stanowi jedynie moment w immanentnym procesie logicznego samorozwoju ducha. Nie rozjaśnia to jednak pojęcia dyktatury. Tym bardziej interesujące jest pojmowanie dyktatury przez katolickich filozofów państwa, jak Bonald, Görres i Donoso Cortés, ponieważ w centralizacji dokonanej przez absolutyzm i jakobinizm, a tym samym w nowożytnym państwie, które w swoim jądrze okazuje się dyktaturą, widzą oni dzieło racjonalizmu, które samo może być przezwyciężone tylko przez dyktaturę. W ten sposób owi wielcy katolicy zbiegają się w szczegółach argumentacji ze zwolennikami dyktatury proletariatu. Istota pojęcia dyktatury leży w tym, że konstytuuje ono wyjątek od organicznego rozwoju, by uzasadnić zadanie usunięcia mechanicznej przeszkody, leżącej na drodze immanentnego ruchu historycznego. Dzięki pojęciu immanentnego, organicznego rozwoju powstaje przeciwieństwo dla mechanistycznego i scentralizowanego państwa. Akceptacja pouvoir constituant ludu zostaje utrzymana w mocy, tylko że proletariat zostaje utożsamiony z ludem. Walka $\mathrm{z}$ intelektualistyczno-mechanicznym racjonalizmem poprzez filozofię irracjonalizmu doprowadziła u Georges'a Sorela do rezultatów anarchistycznych, stanowiących istotną filozoficzną podstawę myśli Bakunina i Kropotkina. Każda organizacja stworzona z planową hierarchią okazuje się próbą intelektualistycznego ingerowania z zewnątrz w postęp i jest określana dyktaturą, tak że organizacja Kościoła katolickiego, oddzielająca teologiczny kler od prowadzonego przezeń laikatu, jest dyktaturą, podczas gdy u Sorela tam, gdzie chodzi o krytykę nowożytnego państwa, występują zdania, które dosłownie mogłyby być napisane na historyczno-politycznych kartach lat trzydziestych. Najczystsza realizacja dyktatury jest dla Sorela praktyką Konwentu Narodowego od 1793 roku, którą odróżnia on jako typowo racjonalistyczną dyktaturę od proletariackiej violence créatrice [twórcza przemoc (fr.)], działającej z intuicją swego znaczenia historycznego.

Przedstawiłem tutaj tę krótką, pozostającą wyłącznie w ramach ogólnych uwag perspektywę, która uprzedza szczegółowe omówienie, by zwrócić uwagę na systematyczny związek, w którym samo pojęcie dyktatury proletariatu należy potraktować wyczerpująco. Krytyka uwag Marksa, Engelsa, Lenina i Trockiego, co ostatnio nieporównywalnie uczynił H. Kelsen, Sozialismus und Staat. Eine Untersuchung der politischen Theorie des Marxismus, Leipzig 1920, mimo wartościowego wyjaśnienia, które musi ze sobą przynieść każde rozważanie tego uczonego, nie dotyka jądra problemu, ponieważ ignoruje ogromne związki pomiędzy ideami. Fakt, że w pismach Kelsena (s. 56) pojawia się antropologiczny argument o naturze człowieka, jest tutaj przedmiotem szczególnego zainteresowania, ponieważ ma on obecnie służyć demokracji, po tym, jak w swojej szczególnej historii absolutystyczna forma państwa zrobiła z niego użytek (por. C. Schmitt, Die Diktatur..., s. 9, 111 i n.). 
który mógł orzec jej zawieszenie. Wskutek tego Konwent działał, powołując się bezpośrednio na pouvoir constituant ludu, wobec którego jednocześnie utrzymywał, że nie był zdolny do wykonywania władzy w czasie wojny i kontrrewolucji. Określił swoją władzę „rewolucyjną”. Według Aularda ${ }^{23}$ było to jedynie przyznanie, że zlikwidowano podział władz, który zgodnie z art. 16 Deklaracji praw człowieka z 1789 roku stanowił cechę charakterystyczną dla konstytucji. Konstytucja z 1793 roku nie wymieniała podziału władzy wśród praw podstawowych. Była zgodna z ówczesnym użyciem języka, określając uchylenie podziału władz jako stan wyjątkowy. W przypadku dyktatury usunięto ten podział, rozumiany jako rozgraniczenie kompetencji w sensie prawnym, ponieważ komisariat jest kierowany merytorycznie wyłącznie przez reguły rzeczowe, a nie normy prawne. Uchylenie podziału władz nie wyróżnia jednak dyktatury w sposób wystarczająco określony od innych fenomenów, jak absolutyzm, despotyzm czy tyrania ${ }^{24}$. W najogólniejszym sensie każdy wyjątek od stanu określanego mianem prawidłowego może zostać nazwany dyktaturą, tak że to słowo określa wyjątek raz od demokracji, raz od zagwarantowanych konstytucyjnie wolności, raz od podziału władz, czy też (jak w dziewiętnastowiecznej filozofii historii) od organicznego rozwoju

\footnotetext{
A. Aulard, Histoire de la révolution française, wyd. 4, s. 315.

Pogląd, który wyraziłem w rozprawie o dyktaturze i stanie oblężenia (C. Schmitt, Eine staatsrechtliche Studie, „Zeitschrift für die gesamte Staatswissenschaft” 1916, nr 38, s. 138 i n.), zdominował rozważania dotyczące prawa państwowego zgromadzenia ustawodawczego i dalszego zrzeszenia. W odniesieniu do zgromadzenia ustawodawczego R. Redslob przedstawił swoje poglądy dotyczące władzy konstytucyjnej (R. Redslob, Die Staatstheorien der französischen Nationalversammlung von 1789, Leipzig 1912, s. 151) i podziału władz (tamże, s. $221 \mathrm{i} \mathrm{n}$.). Dla pojęcia dyktatury szczególnie istotne są poza tym rozważania umiarkowanych konserwatystów i liberałów, którzy będąc pod wrażeniem amerykańskiej konstytucji, powtarzają argumenty wyrażone wcześniej przez Hamiltona, Jaya i Madisona w Federaliście. Duże znaczenie tego wpływu, na który wskazał lord Acton (Acton, Lectures on the French revolution, London 1910, s. 37), jest szczególnie wyraźne w dyskusjach na temat weta królewskiego, systemu bikameralnego oraz federalistycznej decentralizacji Francji (przeciwieństwo federalizmu i jakobińskiej dyktatury zostanie zarysowane w kolejnym rozdziale), szczególnie w wypowiedziach takich osób jak Malouet (Arch. Parl. VIII 590), Mounier, który powoływał się na Delolme'a (eod. 410,416), Lally-Tollendal, który zwraca uwagę na Blackstone'a (eod. 514/515) itd. Później mianem dyktatora określano Robespierre'a, Marata, Dantona, Couthona, Custine'a itd.; nazwiska są niezliczone. Mówiono także o „triumvirat des dictateurs" (A. Aulard, Histoire..., s. 203, 263), o kolektywnej dyktaturze Konwentu, Komuny Paryskiej, okręgów wyborczych itd. (por. interesujący esej G. Gautherot, La dictature des sections parisiennes au début de la Révolution, „Revue des Questions Historiques” 1903, nr 1, t. 93, s. 466). Przy obaleniu Robespierre'a krzyczano: „Precz z tyranami!”, a 18 brumaire'a przed udanym zamachem stanu: „Precz z dyktatorem!”. Szczególnie ciekawy jest fakt, że Marat, który u Kropotkina w Geschichte der Französischen Revolution wydaje się prawie anarchistą w rodzaju Bakunina czy Sorela, postulował dyktaturę; por. A. Aulard, Histoire..., s. 263, a przede wszystkim wygłoszoną przed Konwentem mowę Marata z 25 września 1792 roku, w której sprzeciwiał się „mouvements impétueux et désordonnés du peuple", którymi musi kierować mądry człowiek.
} 
rzeczy. Pojęcie to pozostaje jednak zawsze w funkcjonalnej zależności od istniejącej bądź przedstawianej konstytucji. Wyjaśnia to uogólnienie tego pojęcia. Zgodność co do niego zasadza się jednak wyłącznie na rzeczach negatywnych i dlatego nie jest zbyt trafne. Słowo to było niegdyś ulubionym sloganem. „On parle sans cesse de dictature", powiedział Barère w mowie z 5 kwietnia 1793 roku, którą uzasadnił utworzenie Komitetu Ocalenia Publicznego (Comité de salut public). Pojęcie to lepiej niż przez czystą negację podziału władz opisał Condorcet w eseju Sur le sens du mot Révolutionnaire. Jako osiemnastowieczny racjonalista był daleki od powołania podziału władz, dla którego brakowało mu zrozumienia. Wychodził od założenia o współistnieniu ludzi i uznawał, że umowa państwowa nie może zachować ważności, opierając się tym, którzy chcą ją rozwiązać. Za tym idzie wyważenie interesów, zakładające przewagę interesów istotniejszych, to znaczy istnienie umowy państwowej, nad prawami człowieka. Jest to na razie jedynie całkowicie pozaprawna logika kolizji. Następnie stwierdza, że słowo „rewolucyjny” oznacza „oddalający się od zasad sprawiedliwości stan faktycznych działań, istniejących jedynie przez nadzwyczajny stan rzeczy". Definiował ustawę rewolucyjną wprost jako loi de circonstance ${ }^{25}$.

Kolejnym pytaniem jest to, kto stanowił podmiot zawierającej się w gouvernement révolutionnaire dyktatury suwerennej. Oficjalnie to słowo nie było uznawane, ponieważ stanowiło pojęcie kontrrewolucyjne ${ }^{26}$, a poza tym za bardzo przypominało o władzy wojskowej, której jako stratéocratie przeważnie obawiali się jakobini. Wspomniana wyżej mowa Barère'a daje mimo to jasny obraz stanu prawnego, znikły natomiast zwykłe przemiany dyktatury Komitetu Ocalenia Publicznego czy Robespierre'a. W mowie nie mogło również zabraknąć wskazania na republikański Rzym, ponieważ w czasie rewolucji i spisków w interesie wolności niezbędne są dyktatorskie autorytety. Nie potrzebuje jednak takich autorytetów, jak wyjaśnia Barère,

zawsze można mówić o dyktaturze (fr.)

J. Condorcet, Sur le sens du mot Révolutionnaire, [w:] ⿷匚uvres, Paris 1804, t. XVIII, s. 18, 20.

E. Zweig, Die Lehre..., s. 392 określił gouvernement révolutionnaire mianem „wielkiego nic”, później zaś jako „panowanie Robespierre'a”, „kolegialną dyktaturę Komitetu Ocalenia Publicznego" (s. 369), następnie wspomniał również o dyktaturze Konwencji (Arch. Parl. LXVI 674, E. Zweig, Die Lehre..., s. 386, przypis 4). Dla teorii państwa ważne jest stwierdzenie Zweiga, który jednak nie poprowadził go dalej: „Kiedy zastosować tutaj wyłącznie kategorie dotyczące prawa państwowego, można powiedzieć, że formalne ustalenia wynikają zawsze wyłącznie z potrzeb społecznych przez zarządzanie administracją (w najszerszym znaczeniu). Całkowity brak prawdziwego tj. (sic) powszechnego stanowienia prawa i jego zastąpienie poprzez akt administracyjny nawiązujący do pojedynczego faktu są prawdziwymi cechami charakterystycznymi tego - jak każdego - rewolucyjnego reżimu".

rząd rewolucyjny (fr.).

${ }^{26}$ Obok loi agraire, „maratyzmu” i „d'Orléans sera Roi”.

rządy wojskowe (fr.). 
kiedy przedstawia utworzenie Komitetu Ocalenia Publicznego, ponieważ Komitet nie powinien dzierżyć żadnych ustawodawczych uprawnień, a Konwent ma pozostać odpowiedzialny. Powinien kontrolować i pobudzać egzekutywę.

Praktyczne znaczenie, które osiągnęło podobno tak niegroźne prawo kontroli, zostanie wykazane w następnym rozdziałe. Argumentacja Barère'a kończy się w każdym wypadku na tym, że Komitet nie sprawował dyktatury, ponieważ nie skupił uprawnień legislatywy i egzekutywy. Oznaczałoby to zatem zwykłe pojęcie dyktatury jako uchylenie podziału władz. W przypadku Konwentu Narodowego legislatywa i egzekutywa były skupione. Kiedy Barère opisywał w swojej mowie Konwent Narodowy jako sprawującego dyktaturę, musiało to jednak uderzać, ponieważ zgodnie z pojęciem dyktatury, jak je rozumiano do osiemnastego wieku, dyktator całkowicie zamyka usta ustawom, choć sam nie może ich wydawać ${ }^{27}$. Mając przed oczyma dyktaturę suwerenną Konwentu, Barère zastosował ten termin inaczej, ponieważ wynikał on z uwzględniającej jedynie dyktaturę komisaryczną terminologii osiemnastego wieku. Jednak, jak kontynuuje, ta dyktatura jest konieczna i zgodna z prawem, ponieważ to lud sprawuje dyktaturę nad samym sobą, więc to dyktatura, którą również mogą tolerować wolni i oświeceni ludzie.

Choć Komitet Ocalenia Publicznego stał się z biegiem czasu niezmiernie wpływowy, z punktu widzenia prawa nie ulega wątpliwości, iż działał on jedynie jako komitet Konwentu i na jego zlecenie. Mieliśmy do czynienia z typową sytuacją, że działający komitet zdominował ustanowione plenum, faktycznie sprawując rządy, a następnie wewnątrz komitetu znów stopniowo wzrastała przewaga pojedynczej osoby. W ciągu trzech miesięcy - od stracenia Dantona do 9 termidora - Robespierre opanował Komitet, a dzięki niemu Konwent, który jednogłośnie przyjmował wszystkie wnioski i projekty. Trzymając się rzeczywistego stanu politycznego, należy dodać, że Komitet Ocalenia Publicznego nie był jedynym komitetem Konwentu. W szczególności Komitet Bezpieczeństwa Powszechnego (Comité de sureté générale) rozwinął niezależną aktywność, której historia nie została jednak jeszcze spisana. Pod względem finansowym komitety pozostawał zawsze zależne od Konwentu. Również politycznie niekoniecznie jest prawdą, jak stwierdza Duguit $^{28}$, że w latach 1792-1795 komitety Konwentu byłyby „véritables dét-

27 Por. C. Schmitt, Die Diktatur..., s. 113 przypis 43. Marat próbował 6 maja 1793 udowodnić, że Komitet Ocalenia Publicznego nie sprawuje dyktatury, za pomocą argumentu, że w przypadku dyktatury prawa milczą (les lois se taisent). Jednocześnie próbował ograniczyć pojęcie dyktatury - że do niej należy przekazywanie nieograniczonej władzy jednej jedynej jednostce, co z resztą przedstawił K. Kautsky, Terrorismus und Kommunismus, Berlin 1919, s. 28. angielski gabinet, rozwijający się zgodnie z „ustawą zawężającą”, posiadaczem „absolutnej, 
enteurs du pouvoir"”. Na dłuższą metę, jak okazało się 9 termidora, instancją decydującą politycznie pozostał Konwent Narodowy. Nikt nie neguje, że w sensie prawnym jedynie Konwent wchodził w rachubę. Komisarze ludowi od niego wywodzili swoje pełnomocnictwa, powoływali się na jego toutepuissance, kiedy stawiano im na prowincji śmieszny, jak mówili, zarzut braku podziału władzy; cała ich działalność polegała tylko na tym, by uzyskać władzę Konwentu i w sytuacjach krytycznych, kiedy bez szczególnego polecenia działali na własne ryzyko, jak w przypadku zdrady Dumourieza, powoływali się oni wyłącznie na autorytet Konwentu. On zawsze zachowuje impulsion. Cały autorytet państwa, który z taką bezpośredniością i brakiem hamulców rozwinął się w latach 1792-1795 we Francji, miał swoje źródło w Konwencie Narodowym, „emanował” z niego, jak lubiono wówczas powtarzać, a jego pełnomocnictwa były bezpośrednimi emanacjami uznanej przez niego pouvoir constituant.

PRZEŁOŻY A KINGA MARULEWSKA

$\infty$

JAKUB CHMIELNIAK

Wydział Polonistyki UJ, Instytut Studiów Regionalnych UJ

\title{
Epoka techniki, pokoju i depolityzacji: wstęp do lektury Carla Schmitta
}

\begin{abstract}
arl Schmitt (1888-1985) należy do grona myślicieli, których nazwiska elektryzują, a prace stanowią nieprzerwaną intelektualną stymulację dla kolejnych pokoleń czytelników. Zarazem pozostaje on człowiekiem, którego idee były i są w znacznym stopniu wykorzystywane do prokurowania wzajemnej krytyki przez intelektualistów z obu stron sceny politycznej, co utrudnia ich pełny odbiór i całkowite zrozumienie. Problematyczność, jak się wydaje, wynika z niepełnej analizy moralno-egzystencjalnych przesłanek, które pobudzały niemieckiego prawnika do poszukiwań intelektualnych. Od-
\end{abstract}

wręcz dyktatorskiej władzy państwowej" (R. Hübner, Die parlamentarische Regierungsweise Englands, Tübingen 1918, s. 38) i następnie, z racji tego, że „pełnomocnik co do siły przerósł swego zleceniodawcę", a pierwszy minister zajmował kluczową pozycję, mówić o jego „nieukrywanej dyktaturze”.

prawdziwymi posiadaczami władzy (fr.) 